\title{
Combined Application of Antagonist and Azoxystrobin on Plant Biometrics and Fusarium Wilt Incidence of Tomato
}

\author{
K. Murugavel and R. Kannan* \\ JKKMCAS, Gobi, Department of Plant Pathology, Faculty of Agriculture, \\ Annamalai University, India \\ *Corresponding author
}

\section{A B S T R A C T}

Tomato (Solanum lycopersicum L.) is one of the most widely grown vegetable crops in the world; they are excellent source of various micronutrients and antioxidants. In Tamil Nadu the area under tomato cultivation is 38.78 lakh ha with the production of 841.21 million tonnes. In Tamil Nadu, the major tomato producing districts are Vellore, Salem,

\section{Keywords}

Antagonist, Azoxystrobin, Plant biometrics and Fusarium Wilt

Article Info

Accepted:

14 June 2020 Available Online: 10 July 2020 Dharmapuri, Coimbatore, Trichy, Thiruvannamalai, Madurai, Dindugul, Erode and Krishnagiri. PKM 1, Marutham, Paiyur1, COTH 2 and Sivam are the important varaities/hybrids grown in Tamil Nadu. Among various diseases, Fusariumwilt of tomato caused by Fusarium oxysporum f.sp lycopersici (Sacc.) Synder and Hansenis considered as one of the major constraints to tomato production. Many effective pesticides have been tested against the pathogen but not considered as long term solution. Therefore, the present investigations were undertaken with an objective to isolate and test effective B. subtilis and Trichoderma viride along with the new generation fungicide Azoxystrobin 23\% SC against wilt disease of tomato and assess the molecular mechanisms involved in the disease suppression. Combined application of seed treatment with consortium (B.subtilis and T.viride)@10.0 ml / Kg of seeds+ seedling root dip of consortium (B.subtilis and T.viride) @ 500ml/10 lit of water + Azoxystrobin 23\% SC as Foliar Spray @ 0.1\% on 45 DAT significantly reduced the tomato Fusariumwilt to the minimum and increased the plant growth and yield parameters of tomato to the maximum under pot culture and field condition. Thus, the results of the present study have clearly proved that with the combination of seed treatment seedling root dip of consortium (B.subtilis and T. viride) along with the new chemical Azoxystrobin 23\% SC, it is possible to reduce the amount of chemical being used and also to reduce the number of applications viz., with only one spray of the chemical at 45 DAT the tomato Fusarium wilt incidence could effectively be managed with enhanced fruit yield of Tomato.

\section{Introduction}

Tomato (Solanum lycopersicum L.) is one of the most widely grown vegetable crops in the world (Pastor et al., 2012). Tomato is used for consumption due to its high nutritive values, antioxidant and curative properties (Sahu et al., 2013). Tomatoes are excellent source of various micronutrients and antioxidants. Therefore, they are often recommended by 
dieticians and nutritionists for controlling cholesterol and weight reduction (Lenucci et al., 2006, Keswani, 2015). Tomato contains high levels of vitamin C, lycopene, and Bcarotene, which are anti-oxidants that promote good health. The nutritional quality of tomato is mainly determined by its carotenoid, potassium, vitamin $\mathrm{C}$ and vitamin A content. Ripe tomatoes have high levels of carotenoids, of which carotenes make up between 90 and 95\% (Guil-Guerrero and Rebolloso-Fuentes, 2009). 'Lycopene' produced only by tomato is a natural antioxidant that works effectively to slow the growth of the cancerous cells (Bhovomik et al., 2012).

China ranks first in the world with an area of 14.5 lakh hectares and 41.626 million tonnes of production per annum (Anon., 2015). India occupies second position in the world with respect to area, but occupies only fifth place in terms of production. Total area under tomato cultivation in India is 773.9 lakh ha with a production of 18732.0 million tonnes (Horticultural Database, 2017 provisional). Tomato plant is susceptible to various diseases caused by different agents such as bacteria, viruses, nematode, fungi and abiotic factors (Sahu et al., 2013). Among the fungal diseases, wilt caused by Fusarium oxysporum f. sp. lycopersici is an economically important and destructive disease of tomato crop worldwide (Jones et al., 1991). The fungus Fusarium oxysporum f. sp. lycopersici is exerting production losses between 30 to $40 \%$ and may even reach up to $80 \%$ if, climatic conditions favor the growth of the fungus (Lukyanenko, 1991, Nirmaladevi, 2016). Many effective fungicides have been tested against the Fusarium wilt pathogens but not considered as long term solution because of concerns about health and environmental hazards, expensiveness, development of resistance to pesticides (Stammler et al., 2006). Besides, the chemicals pose health hazards to applicators as well as the consumers (Sundaramoorthy, 2013). The nonavailability of specific fungicide and lack of resistant varieties also aggravate the problem. Therefore, a need for alternative methods of control of wilt complex pathogens has become vital and several researchers have also reported alternative disease management strategies (Singh et al., 2003).

Biological control of soil borne diseases using antagonistic microorganisms are accepted as a durable and ecofriendly alternative for agrochemicals. The antagonistic fungi especially Trichoderma spp viz., $T$. harzianum, T. atroviride and T.longibrachiatum have been widely used against $F$. solani and $F$. oxysporum f.sp. lycopersici (Ahmed, 2011; Hand and Perveen, 2012). Bacillus subtilis is also having significant antagonistic activity against $F$. oxysporum in both laboratory and in vivo conditions. The B.subtillis strain EU07 reduced the incidence of disease caused by $F$. oxysporum f. sp. lycopersici by $75 \%$ (Rocha, 2017) consortium.

The long term effective management usually uses integration of two or more disease control measures (Fazil and Ishtiaq, 2010).Hence; it was thought that integration of a PGPR with the new fungicide could enhance the disease suppression and also reduce the amount of fungicides applied to the crop. New generation fungicides have proved as a new ray of hope in better management of diseases under field conditions (Ravikumar, 2017). Azoxystrobin is one an efficient fungicide belongs to the strobilurins, group of fungicides (Margot et al., 1998). Azoxystrobin a naturally occurring broad spectrum new generation fungicide extracted from the mushroom fungi Strobilurus tenacellus with protectant, curative, eradicant and systemic properties, is found to be very effective in controlling various fungal 
diseases (Sundravadana et al., 2007) combination with bioagent. Recent works also revealed that the biocontrol agents T.viride and B. subtilis were used against many soil borne diseases along with the fungicides especially Azoxystrobin (Mohiddin and Khan, 2013; Ranganathswamy et al., 2013; Saxena et al., 2014).

\section{Materials and Methods}

Effect of combined application of antagonist and Azoxystrobin on plant growth and Fusarium wilt incidence of tomato (pot culture)

Sterilized soil was mixed with the pathogen inoculums@5per cent (W/W) level and filled in $1 \times 1 \times 1$ feet cement pots. The most effective soil application dosages identified as earlier experiment alone were used for testing the efficacy of soil application of the antagonists. The tomato seeds were treated with the antagonists and Azoxystrobin as seed treatment and after planted in the pot soil mixed with the inoculum of F.oxysporum f.sp. lycopersici alone served as a control. Carbendazim @ $0.1 \%$ was used for comparison. The experiment was conducted with three replication in a randomized block design.

\section{Treatment schedule}

$\mathrm{T}_{1}$ - Seed treatment with consortium (T.viride \&B.subtilis) @ 10ml $/ \mathrm{kg}$ of seed

$\mathrm{T}_{2}-$ Seedling root dip of consortium (T.viride \& B.subtilis) @ 500ml/10 lit of water

$\mathrm{T}_{3}-\mathrm{T}_{1}+\mathrm{T}_{2}$

$\mathrm{T}_{4}$ - Seed treatment with Azoxystrobin @ $2 \mathrm{ml} / \mathrm{kg}$ of seed

$\mathrm{T}_{5}-$ Seed treatment with Azoxystrobin @ $2 \mathrm{ml} / \mathrm{kg}$ of seed+ Foliar spray with azoxystrobin@0.1\%@45 DAT

$\mathrm{T}_{6}-$ Seed treatment with Azoxystrobin @ $2 \mathrm{ml} / \mathrm{kg}$ of seed+ Foliar spray with
azoxystrobin@0.1\%@45DAT and60DAT $\mathrm{T}_{7}-\mathrm{T}_{3}+$ Foliar spray with azoxystrobin @0.1\%@45 DAT

$\mathrm{T}_{8}-\mathrm{T}_{3}+$ Foliar spray with azoxystrobin @0.1\%@45 DAT and 60 DAT

$\mathrm{T}_{9}-$ Seed Treatment with Carbendazim 50\% WP @ 2g/ kg of seed+ Foliar spray with azoxystrobin@0.1\%@45 and 60DAT

$\mathrm{T}_{10^{-}}$Control

The treatments where given as per the schedule. All the observations viz., Fusarium wilt incidence, plant growth parameters viz., plant height, no of fruits per plant and yield per plant were recorded at 30 DAT, 60 DAT, 90 DAT and at final harvest.

Effect of combined application of antagonist and Azoxystrobin on plant biometrics and Fusarium wilt incidence of tomato (pot culture)

A field trial were conducted in Fusarium wilt prone farmer's field at perungulathur village in Thiruvannamalai district of Tamilnadu 2018-2019, representing irrigated conditions by integrating the best treatments identified in the pot culture experiments. The blanket fertilizer schedule of NPK 75:100:50 kg / ha recommended by the Tamilnadu agriculture university was followed. A plot size of $20 \mathrm{~m}^{2}$ was used for each treatment. Each treatment was replicated thrice and a suitable control was also maintained.

\section{Treatment schedule}

$\mathrm{T}_{1}$ - Seed treatment with consortium (T.viride \& B.subtilis) @ 10ml/kg of seed

$\mathrm{T}_{2}$ - Seedling root dip of consortium (T.viride \&B.subtilis) @ 500ml/10 lit of water

$\mathrm{T}_{3}-\mathrm{T}_{1}+\mathrm{T}_{2}$

$\mathrm{T}_{4}$ - Seed treatment with Azoxystrobin @ $2 \mathrm{ml} / \mathrm{kg}$ of seed

$\mathrm{T}_{5^{-}}$Seed treatment with Azoxystrobin @ $2 \mathrm{ml} / \mathrm{kg}$ of seed+ Foliar spray with 
azoxystrobin@0.1\%@45DAT

$\mathrm{T}_{6 \text { - }}$ Seed treatment with Azoxystrobin @ $2 \mathrm{ml} / \mathrm{kg}$ of seed+ Foliar spray with azoxystrobin@0.1\%@45 DAT and 60DAT $\mathrm{T}_{7^{-}} \mathrm{T}_{3}+$ Foliar spray with azoxystrobin @0.1\%@45 DAT

$\mathrm{T}_{8}-\mathrm{T}_{3}+$ Foliar spray with azoxystrobin @0.1\% @ 45 DAT and 60 DAT

$\mathrm{T}_{9}$ - Seed Treatment with Carbendazim 50\% WP @ 2g/ kg of seed+ Foliar spray with azoxystrobin@ 0.1\%@45 and 60 DAT $\mathrm{T}_{10^{-}}$Control

The treatments where given as per the schedule. All the observations viz., Fusarium wilt incidence, plant growth parameters viz., plant height, no of fruits per plant and yield/ha were recorded at $30 \mathrm{DAT}, 60 \mathrm{DAT}$, 90 DAT and at final harvest.

\section{Results and Discussion}

Effect of Consortium (T. viride + B.subtilis) and Azoxystrobin 23\% SC on the biometrics of Tomato var. PKM 1 (Pot culture)

The results obtained on the efficacy of combined application of antagonists and Azoxystrobin 23\% SC are furnished in table 1. Among the treatments the combination treatment of seed treatment with consortium (T.viride\& B.subtilis) @ $10 \mathrm{ml} / \mathrm{kg}$ of seed + seedling root dip of consortium (T.viride \& B.subtilis)@500ml/10 lit of water+ foliar spray of Azoxystrobin 23\% SC @ $0.1 \%$ @ 45 $\operatorname{DAT}\left(\mathrm{T}_{7}\right)$ recorded the maximum germination percentage (94.69\%), plant height (126.83 $\mathrm{cm})$, no. of fruits per plant (23.45) and fruit yield $(2.00 \mathrm{~kg} /$ plant $)$ which was at par with the treatment $\mathrm{T}_{8}$ (T3+ foliar spray @ 45 DAT and 60 DAT) recorded germination percentage $(93.50 \%)$, plant height $(117.65 \mathrm{~cm})$, no. of fruits per plant (21.67) and fruit yield $(1.73 \mathrm{~kg} / \mathrm{plant})$ and they were followed by the treatments $\mathrm{T}_{6}, \mathrm{~T}_{3}, \mathrm{~T}_{5}, \mathrm{~T}_{4}, \mathrm{~T}_{7}, \mathrm{~T}_{2}$ and $\mathrm{T}_{1}$ is the decreasing order of merit. The control recorded the least biometric values of germination percentage $(64.98 \%)$, plant height $(89.34 \mathrm{~cm})$, no. of fruits per plant (15.32) and fruit yield (0.89kg/plant).

Combined application of Azoxystrobin 23\% SC and consortium (T.viride \& B.subtilis) on the Fusarium wilt incidence of tomato var. PKM 1 (field trial)

The results depicted in table 2 of the pot trial showed that the Fusariumwilt incidence was effectively reduced by the treatment Seed treatment with Azoxystrobin 23\% SC @ $2 \mathrm{ml} / \mathrm{kg}$ of seed+ foliar spray @ 45 DAT and $60 \mathrm{DAT}\left(\mathrm{T}_{6}\right)$ which recorded the least disease incidence $(5.98 \%, 9.65 \%, 12.93 \%$ and $13.64 \%$ at 30DAT, 60DAT, 90DAT and at final harvest respectively). Which was at par with the treatment T3+ Foliar spray of Azoxystrobin 23\% SC 0.1\% @ 45 DAT and 60 DAT (T8) recorded (6.23\%, 9.86\%, $13.86 \%$ and $14.75 \%$ at 30DAT, 60DAT, 90DAT and at final harvest respectively). T3+ foliar spray of Azoxystrobin 23\% SC 0.1\% @ 45 DAT $\left(\mathrm{T}_{7}\right)$ recorded $(6.53 \%, 10.23 \%$, $13.38 \%$ and $14.36 \%$ at 30DAT, 60DAT, 90DAT and at final harvest respectively). Whereas control recorded the maximum wilt incidence of $(20.86 \%, 34.96 \%, 50.32 \%$ and $63.25 \%$ at 30DAT, 60DAT, 90DAT and at final harvest respectively)

Effect of Consortium (T. viride + B.subtilis) and Azoxystrobin $23 \%$ SC on the biometrics of Tomato var. PKM 1 (field trial)

The results obtained on the efficacy of combined application of antagonists and Azoxystrobin 23\% SC are furnished in table 3. 
Table.1 Combined application of Azoxystrobin 23\% SC and consortium (T.viride \& B.subtilis) on the plant biometrics of tomato(Pot culture)

\begin{tabular}{|c|c|c|c|c|}
\hline \multirow[t]{2}{*}{ Tr.No } & \multirow[t]{2}{*}{ Treatment } & \multicolumn{3}{|c|}{ Plant biometrics } \\
\hline & & Plant height & $\begin{array}{c}\text { No. Of } \\
\text { fruits/plant }\end{array}$ & Yield/ plant \\
\hline $\mathbf{T}_{1}$ & Seed treatment with consortium (T.viride \& B.subtilis) @ 10ml $/ \mathrm{kg}$ of seed & $95.84^{\mathrm{i}}$ & $16.85^{\mathrm{i}}$ & $1.22^{\mathrm{i}}$ \\
\hline $\mathbf{T}_{2}$ & Seedling root dip of consortium (T.viride \& B.subtilis) @ 500ml/10 lit of water & $96.54^{\mathrm{h}}$ & $16.25^{\mathrm{h}}$ & $1.17^{\mathrm{h}}$ \\
\hline $\mathbf{T}_{3}$ & $\mathrm{~T}_{1}+\mathrm{T}_{2}$ & $115.25^{\mathrm{c}}$ & $21.34^{\mathrm{c}}$ & $1.72^{\mathrm{c}}$ \\
\hline $\mathbf{T}_{4}$ & Seed treatment with Azoxystrobin 23\% SC @ 2ml $/ \mathrm{kg}$ of seed & $102.35^{\mathrm{f}}$ & $20.86^{\mathrm{f}}$ & $1.62^{\mathrm{f}}$ \\
\hline $\mathbf{T}_{5}$ & $\begin{array}{l}\text { Seed treatment with Azoxystrobin 23\% SC @ } 2 \mathrm{ml} / \mathrm{kg} \text { of seed+ Foliar spray } \\
\text { with Azoxystrobin 23\% SC @0.1\% @ 45 DAT }\end{array}$ & $103.37^{\mathrm{e}}$ & $21.85^{\mathrm{e}}$ & $1.71^{\mathrm{e}}$ \\
\hline $\mathbf{T}_{6}$ & $\begin{array}{l}\text { Seed treatment with Azoxystrobin 23\% SC @ } 2 \mathrm{ml} / \mathrm{kg} \text { of seed+ Foliar spray } \\
\text { with Azoxystrobin 23\% SC @0.1\% @ 45 DAT and 60 DAT }\end{array}$ & $116.79^{c}$ & $22.64^{\mathrm{c}}$ & $1.81^{\mathrm{c}}$ \\
\hline $\mathbf{T}_{7}$ & $\mathrm{~T}_{3}+$ Foliar spray with Azoxystrobin 23\% SC @0.1\% @ 45 DAT & $126.83^{\mathrm{a}}$ & $23.45^{\mathrm{a}}$ & $2.00^{\mathrm{a}}$ \\
\hline $\mathbf{T}_{8}$ & $\mathrm{~T}_{3}+$ Foliar spray with Azoxystrobin 23\% SC @0.1\% @ 45 DAT and 60 DAT & $117.65^{\mathrm{a}}$ & $21.67^{\mathrm{a}}$ & $1.73^{\mathrm{a}}$ \\
\hline $\mathbf{T}_{9}$ & $\begin{array}{l}\text { Seed Treatment with Carbendazim 50\% WP @ 2g/ kg of seed+ Foliar spray } \\
\text { with Azoxystrobin 23\% SC @0.1\% @45 and 60 DAT }\end{array}$ & $98.49^{\mathrm{g}}$ & $18.64^{\mathrm{g}}$ & $1.39^{\mathrm{g}}$ \\
\hline $\mathbf{T}_{10}$ & Control & $89.34^{\mathrm{j}}$ & $15.32^{\mathrm{j}}$ & $0.89^{j}$ \\
\hline
\end{tabular}

* Mean of three replications

* In a column, means followed by a common letter are not significantly differ at 5\% level by Duncan's multiple range test (DMRT) 
Table.2 Combined application of Azoxystrobin 23\% SC and consortium (T.viride \& B.subtilis) on the Fusarium wilt incidence of tomato (Field trial)

\begin{tabular}{|c|c|c|c|c|c|c|c|c|c|}
\hline Tr.No & Treatment & \multicolumn{4}{|c|}{ Wilt incidence(\%) } & \multicolumn{4}{|c|}{ Percent decrease over control } \\
\hline $\mathbf{T}_{1}$ & $\begin{array}{l}\text { Seed treatment with consortium } \\
\text { (T.viride\&B.subtilis)@ 10ml } / \mathrm{kg} \text { of seed }\end{array}$ & $\begin{array}{l}11.96^{\mathrm{i}} \\
(20.23)\end{array}$ & $\begin{array}{l}19.55^{\mathrm{i}} \\
(26.24)\end{array}$ & $\begin{array}{l}26.25^{\mathrm{i}} \\
(30.82)\end{array}$ & $\begin{array}{l}29.25^{\mathrm{i}} \\
(32.74)\end{array}$ & 42.58 & 44.07 & 47.83 & 53.75 \\
\hline $\mathbf{T}_{2}$ & $\begin{array}{l}\text { Seedling root dip of consortium } \\
\text { (T.viride\&B.subtilis)@ } 500 \mathrm{ml} / 10 \text { lit of } \\
\text { water }\end{array}$ & $\begin{array}{l}11.43^{\mathrm{h}} \\
(19.76)\end{array}$ & $\begin{array}{c}17.35^{\mathrm{h}} \\
(24.61)\end{array}$ & $\begin{array}{c}22.98^{h} \\
(28.64)\end{array}$ & $\begin{array}{c}27.43^{h} \\
(31.58)\end{array}$ & 45.12 & 50.76 & 54.33 & 56.63 \\
\hline $\mathbf{T}_{3}$ & $\mathrm{~T}_{1}+\mathrm{T}_{2}$ & $\begin{array}{c}9.05^{\mathrm{f}} \\
(17.50)\end{array}$ & $\begin{array}{l}13.89^{f} \\
(21.88)\end{array}$ & $\begin{array}{l}16.35^{\mathrm{f}} \\
(23.85)\end{array}$ & $\begin{array}{l}18.96^{\mathrm{f}} \\
(25.81)\end{array}$ & 56.55 & 60.73 & 67.50 & 70.02 \\
\hline $\mathbf{T}_{4}$ & $\begin{array}{l}\text { Seed treatment with Azoxystrobin } 23 \% \\
\text { SC @ } 2 \mathrm{ml} / \mathrm{kg} \text { of seed }\end{array}$ & $\begin{array}{r}10.63^{\mathrm{g}} \\
(19.02)\end{array}$ & $\begin{array}{l}16.23^{\mathrm{g}} \\
(23.75)\end{array}$ & $\begin{array}{l}21.28^{\mathrm{g}} \\
(27.47)\end{array}$ & $\begin{array}{l}24.48^{\mathrm{g}} \\
(29.65)\end{array}$ & 48.96 & 53.99 & 57.71 & 61.29 \\
\hline $\mathbf{T}_{5}$ & $\begin{array}{c}\text { Seed treatment with Azoxystrobin } 23 \% \\
\text { SC @ } 2 \mathrm{ml} / \mathrm{kg} \text { of seed+Foliar spray with } \\
\text { Azoxystrobin 23\% SC @ } 0.1 \% @ 45 \\
\text { DAT }\end{array}$ & $\begin{array}{c}9.85^{\mathrm{e}} \\
(18.29)\end{array}$ & $\begin{array}{c}16.05^{\mathrm{e}} \\
(23.61)\end{array}$ & $\begin{array}{c}20.25^{\mathrm{e}} \\
(26.74)\end{array}$ & $\begin{array}{c}21.78^{e} \\
(27.81)\end{array}$ & 52.71 & 54.51 & 59.75 & 65.56 \\
\hline $\mathbf{T}_{6}$ & $\begin{array}{c}\text { Seed treatment with Azoxystrobin } 23 \% \\
\text { SC @ } 2 \mathrm{ml} / \mathrm{kg} \text { of seed+ Foliar spray with } \\
\text { Azoxystrobin 23\% SC @0.1\% @ } 45 \\
\text { DAT and 60 DAT }\end{array}$ & $\begin{array}{c}5.98^{\mathrm{a}} \\
(14.15)\end{array}$ & $\begin{array}{c}9.65^{\mathrm{a}} \\
(18.09)\end{array}$ & $\begin{array}{c}12.93^{\mathrm{a}} \\
(21.07)\end{array}$ & $\begin{array}{c}13.64^{\mathrm{a}} \\
(21.67)\end{array}$ & 71.33 & 72.39 & 74.30 & 78.43 \\
\hline $\mathbf{T}_{8}$ & $\begin{array}{c}\mathrm{T}_{3}+\text { Foliar spray with Azoxystrobin 23\% } \\
\text { SC @0.1\% @ 45 DAT and 60 DAT }\end{array}$ & $\begin{array}{l}6.53^{\mathrm{b}} \\
(14.8)\end{array}$ & $\begin{array}{l}10.23^{b} \\
(18.65)\end{array}$ & $\begin{array}{l}13.38^{\mathrm{b}} \\
(21.45)\end{array}$ & $\begin{array}{l}14.36^{\mathrm{b}} \\
(22.26)\end{array}$ & 68.65 & 71.28 & 73.41 & 77.28 \\
\hline $\mathbf{T}_{9}$ & $\begin{array}{l}\text { Seed Treatment with Carbendazim } 50 \% \\
\text { WP @ 2g/ kg of seed+ foliar spray @ } 45 \\
\text { and } 60 \text { DAT }\end{array}$ & $\begin{array}{c}9.46^{\mathrm{d}} \\
(17.91)\end{array}$ & $\begin{array}{c}14.56^{d} \\
(22.43)\end{array}$ & $\begin{array}{c}18.89^{d} \\
(25.76)\end{array}$ & $\begin{array}{c}20.89^{d} \\
(27.19)\end{array}$ & 54.58 & 58.80 & 62.46 & 66.97 \\
\hline $\mathbf{T}_{10}$ & Control & $\begin{array}{l}20.86^{\mathrm{j}} \\
(27.17)\end{array}$ & $\begin{array}{c}34.96^{\mathrm{j}} \\
(36.24)\end{array}$ & $\begin{array}{c}50.32^{\mathrm{j}} \\
(45.18)\end{array}$ & $\begin{array}{c}63.25^{\mathrm{j}} \\
(52.68)\end{array}$ & - & - & - & - \\
\hline
\end{tabular}

* Mean of three replications

* In a column, means followed by a common letter are not significantly differ at $5 \%$ level by Duncan's multiple range test (DMRT) 
Table.3 Combined application of Azoxystrobin 23\% SC and consortium (T.viride \& B.subtilis) on the plant biometrics of tomato (Field trial)

\begin{tabular}{|c|c|c|c|c|}
\hline \multirow[t]{2}{*}{ Tr.No } & \multirow[t]{2}{*}{ Treatment } & \multicolumn{3}{|c|}{ Plant biometrics } \\
\hline & & Plant height & No. Of fruits/plant & Tonnes / ha \\
\hline $\mathbf{T}_{1}$ & $\begin{array}{l}\text { Seed treatment with consortium (T.viride\&B.subtilis)@ } \\
10 \mathrm{ml} / \mathrm{kg} \text { of seed }\end{array}$ & $97.33^{\mathrm{i}}$ & $16.85^{\mathrm{i}}$ & $25.36^{\mathrm{i}}$ \\
\hline $\mathbf{T}_{2}$ & $\begin{array}{c}\text { Seedling root dip of consortium (T.viride\&B.subtilis) @ } \\
500 \mathrm{ml} / 10 \text { lit of water }\end{array}$ & $98.39^{\mathrm{h}}$ & $17.29^{\mathrm{h}}$ & $26.24^{\mathrm{h}}$ \\
\hline $\mathbf{T}_{3}$ & $\mathrm{~T}_{1}+\mathrm{T}_{2}$ & $115.21^{\mathrm{c}}$ & $23.64^{\mathrm{c}}$ & $30.34^{\mathrm{c}}$ \\
\hline $\mathbf{T}_{4}$ & Seed treatment with Azoxystrobin 23\% SC @ 2ml/kg of seed & $103.96^{\mathrm{f}}$ & $21.55^{\mathrm{f}}$ & $28.76^{\mathrm{f}}$ \\
\hline $\mathbf{T}_{5}$ & $\begin{array}{l}\text { Seed treatment with Azoxystrobin } 23 \% \text { SC @ } 2 \mathrm{ml} / \mathrm{kg} \text { of seed+ } \\
\text { foliar spray Foliar spray with Azoxystrobin 23\% SC @0.1\% } \\
\text { @ 45 DAT }\end{array}$ & $104.87^{\mathrm{e}}$ & $22.94^{\mathrm{e}}$ & $29.64^{\mathrm{e}}$ \\
\hline $\mathbf{T}_{6}$ & $\begin{array}{c}\text { Seed treatment with Azoxystrobin } 23 \% \text { SC @ } 2 \mathrm{ml} / \mathrm{kg} \text { of seed+ } \\
\text { foliar spray Foliar spray with Azoxystrobin 23\% SC @0.1\% } \\
\text { @ 45 DAT and 60 DAT }\end{array}$ & $117.24^{\mathrm{c}}$ & $21.69^{c}$ & $31.54^{\mathrm{c}}$ \\
\hline $\mathbf{T}_{7}$ & $\begin{array}{l}\mathrm{T}_{3}+\text { foliar spray Foliar spray with Azoxystrobin } 23 \% \mathrm{SC} \\
\qquad 0.1 \% @ 45 \mathrm{DAT}\end{array}$ & $131.84^{\mathrm{a}}$ & $24.72^{\mathrm{a}}$ & $33.89^{\mathrm{a}}$ \\
\hline $\mathbf{T}_{8}$ & $\begin{array}{c}\mathrm{T}_{3}+\text { foliar spray Foliar spray with Azoxystrobin 23\% SC } \\
\text { @0.1\% @ 45 DAT and 60 DAT }\end{array}$ & $119.57^{a}$ & $21.74^{\mathrm{a}}$ & $32.46^{\mathrm{a}}$ \\
\hline $\mathbf{T}_{9}$ & $\begin{array}{l}\text { Seed Treatment with Carbendazim 50\% WP @ } 2 \mathrm{~g} / \mathrm{kg} \text { of } \\
\text { seed+ foliar spray @ } 45 \text { and 60 DAT }\end{array}$ & $99.24^{\mathrm{g}}$ & $19.87^{\mathrm{g}}$ & $27.36^{\mathrm{g}}$ \\
\hline $\mathbf{T}_{10}$ & Control & $89.34^{j}$ & $15.47^{j}$ & $24.36^{j}$ \\
\hline
\end{tabular}

* Mean of three replications

* In a column, means followed by a common letter are not significantly differ at 5\% level by Duncan's multiple range test (DMRT) 
Fig.1 Combined application of Azoxystrobin 23\% SC and consortium (T.viride \& B.subtilis) on the Fusarium wilt incidence of tomato (Field trial)

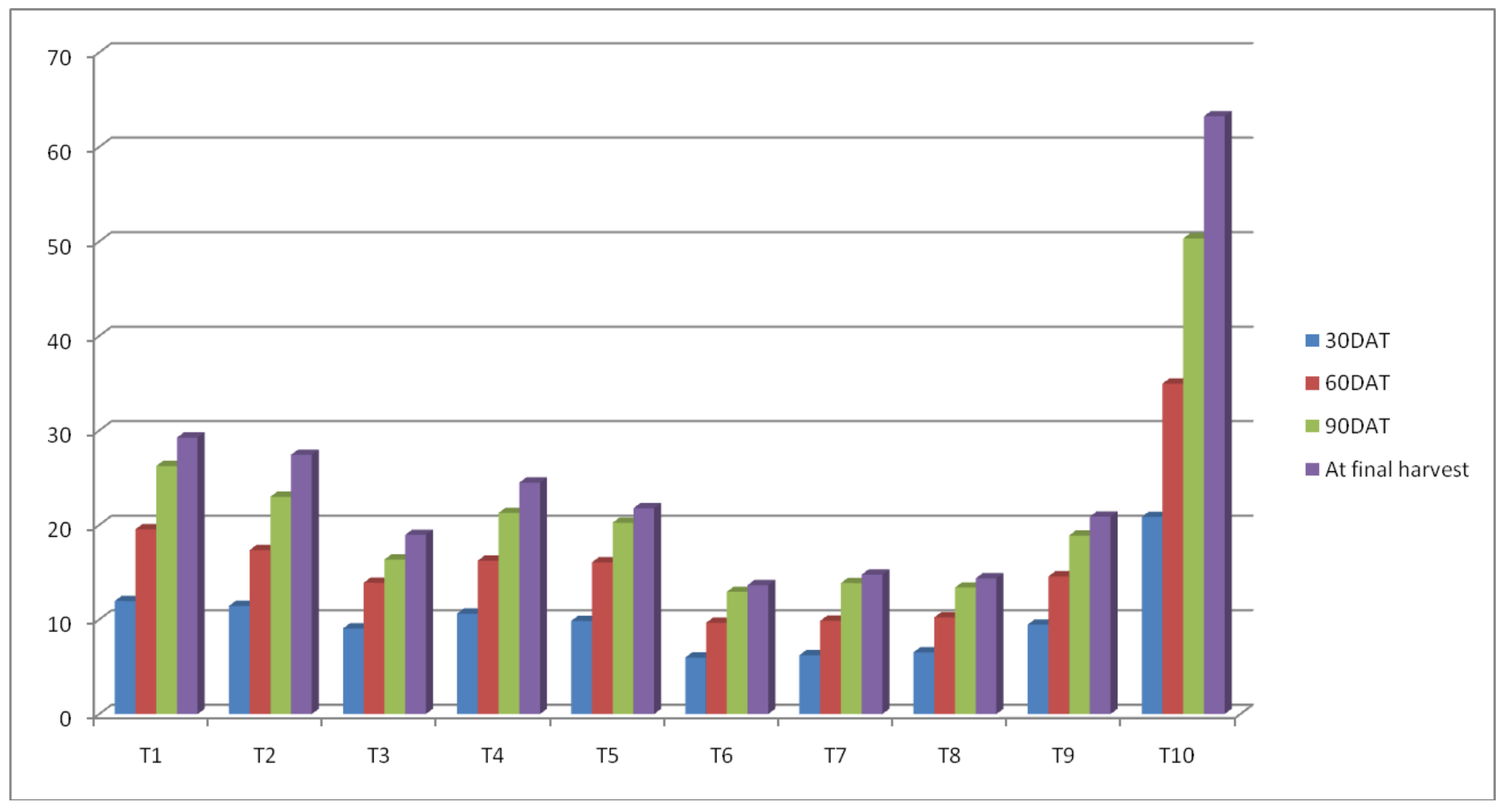


Among the treatments the combination treatment of seed treatment with consortium (T.viride \& B.subtilis) @ $10 \mathrm{ml} / \mathrm{kg}$ of seed + seedling root dip of consortium (T.viride\& B.subtilis) @ 500ml/10 lit of water+ foliar spray of Azoxystrobin 23\% SC @0.1\%@45 DAT $\left(\mathrm{T}_{7}\right)$ recorded the maximum germination percentage $(95.87 \%)$, plant height (131.84 $\mathrm{cm})$, no. of fruits per plant (24.72) and fruit yield $(33.89 \mathrm{t} / \mathrm{ha})$ which was at par with the treatment $\mathrm{T}_{8}\left(\mathrm{~T}_{3}+\right.$ foliar spray @ 45 DAT and 60 DAT) recorded germination percentage $(92.84 \%)$, plant height $(119.57 \mathrm{~cm})$, no. of fruits per plant (21.74) and fruit yield (32.46t/ha) and they were followed by the treatments $\mathrm{T}_{6}, \mathrm{~T}_{3}, \mathrm{~T}_{5}, \mathrm{~T}_{4}, \mathrm{~T}_{7}, \mathrm{~T}_{2}$ and $\mathrm{T}_{1}$ is the decreasing order of merit. The control recorded the least biometric values of germination percentage $(62.98 \%)$, plant height $(89.34 \mathrm{~cm})$, no. of fruits per plant (15.47) and fruit yield (24.36t/ha).

Thus, it is evident that the integration of bio agent with Azoxystrobin resulted in a synergistic effect and resulted in suppression of the disease. The strobilurins bind to one specific site in the mitochondria, the quinol oxidation (Qo) site (or ubiquinol site) of cytochrome $\mathrm{b}$ and thereby stop electron transfer between cytochrome b and cytochrome c, which halts reduced nicotinamide adenine dinucleotide (NADH) oxidation and adenosine triphosphate (ATP) synthesis (Brandt,1993). This leads to the stopping of the energy production and the fungus will eventually die. Also the Strobilurins are having the ability to delay leaf senescence and preserve oxidative balance, which, in turn, can lead to increased yields. Similar to the present observations the mixture B. subtilis + azoxystrobin was found very effective and generally more active than the two components applied alone (Gilardi et al., 2008). Also it has been reported that the combinations of biocontrol agents with $50 \%$ reduction in the dose of fungicides were effective against the fruit rot of chilli (Anand et al., 2010). Integrated use of biocontrol agents with single dose of fungicide was found effective against Fusariumm crown rot and root rot of tomato (Omar et al., 2006). Besides, the synergistic efficacy of antagonists against several pathogens was reported in various crops (Thilagavathi et al., 2007; Rashmi Srivastava et al., 2010; Tayal et al., 2011; Malathi, 2015; Shiva Yendyo et al., 2018).

These reports by the earlier workers lend support to the present investigations. Trichoderma species is considered as promising biological control agents against numerous phytopathogenic fungi since it is able to inhibit the phytopathogenic fungi either by developing resistance and plant defense reaction by releasing volatile and non-volatile metabolites including several unknown sesquiterpenes, diterpenes, and tetraterpenes or by direct confrontation through mycoparasitism and competition or by producing antibiotics (Odebode, 2006). It also produce more than 100 metabolites with antibiotic activities including polyketides, pyrones, terpenes, metabolites derived from amino acids and polypeptides (Sivasithamparam and Ghisalberti 1998).

Besides the disease suppression, secondary metabolites produced by Trichoderma have been reported to play a role in plant growth promotion, the metabolites produced by $T$. koningii (Koninginin A) and T. harzianum (6pentylalpha-pyrone) that acted as plant growth regulators (Cutler et al., 1989). Vinaleet al. (2008), reported that azaphilone, butenolide, harzianopyridone, harzianolide, 1hydroxy-3-methylanthraquinone, $\quad 1,8$ dihydroxy-3-methyl-anthraquinone and 6-npentyl-6H-pyran-2-one (6PP) are the responsible for the plant growth promotion. All these earlier reports corroborates with the present findings. 


\section{References}

Ahmed M (2011) Management of Fusarium wilt of tomato by soil amendment with Trichoderma koningii and a white sterile fungus Indian. J of Res 5: 35-38.

Anand T, Chandrasekaran A, Kuttalam S, Senthilraja S, Samiyappan R (2010). Integrated control of fruit rot and powdery mildew of chilli using the biological agent Pseudomonas fluorescens and a chemical fungicide. Biocontrol 52:1-7.

Anon, (2015) Statistical data of horticultural crops I Tamilnadu.www.tngov.in.

Bhovomik D, Kumar KPS, Paswan S, Srivastava S (2012) Tomato-A Natural Medicine and Its Health Benefits. Journal of Pharmacognosy and Phytochemistry, 1(1): 33.

Brandt U, Haase U, Schaegger H. von Jagow G (1993) Species specificity and mechanism of action of strobilurins DECHEMA Monographien 129; 27-38.

Cutler HG, Himmelsbach DS, Arrendale RF, Cole PD, Cox RH (1989). Koninginin A a novel plant growth regulator from Trichoderma koningii. AgricBiolChem 53 (10); 2605-2611.

Fazil R, Ishtiaq S (2010).Integrated control of Alternariasolani with Trichoderma spp And fungicides under in vitro conditions Sairhad. J Agri 26(4): 613 619.

Francine Yuriko OtsukaRochaa, Cristiana Maia de Oliveiraa, Paula RenataAlves da Silvaa, Leona Henrique Varial de Melob, Margarida Goréte Ferreira do Carmoc, José Ivo Baldani (2017) Taxonomical and functional characterization of Bacillus strains isolated from tomato plants and their biocontrol activity against races 1, 2 and 3 of Fusarium oxysporum f sp lycopersici. Applied Soil Ecology 120 8-19.
Gilardi G, Gullino ML, Garibaldi A (2008) Effect of fungicides and of biocontrol agents against powdery mildew of turnip.Commun Agric Appl Biol Sci. 73(2).

Guil-Guerrero JL, Rebolloso-Fuentes MM (2009) Nutrient composition and antioxidant activity of eight tomato (Lycopersicon esculentum) varieties. Journal of Food Composition and Analysis22: 123-129.

Jones JB, Jones JP, Stall RE, Zitter TA (1991) Compendium of tomato diseases. APS Press, Minnesota.

Keswani C (2015) Proteomics studies of thermotolerant strain of Trichoderma spp. $\mathrm{PhD}$ Thesis, banarashindu university, Varanasi.

Lenucci, MS,Cadinu D, Taurino M, Piro G, Dalessandro G (2006) Antioxidant composition in cherry and high-pigment tomato cultivars. Journal agricultural food chemistry 54: 2006-2613.

Lukyanenko AN (1991) Disease resistance In: Monographs on theoretical and applied genetics -14 (EdGKello). Springer Verlag, Berlin Heidelberg: 99 - 119.

Malathi S (2015) Biological control of onion basal rot caused by Fusarium oxysporum f. sp. cepae.Asian J Bio Sci., 10(1): 21-26.

Margot P, Huggenberger F, Amrein J, Weiss B (1998) CGA 279202: a new broadspectrum strobilurin fungicide In: The Proceedings of the Brighton Crop Protection Conference Farnham, UK. British Crop Protection Council: 375382.

Mohiddin FA, Khan MR (2013) Tolerance of fungal and bacterial biocontrol agents to six pesticides commonly used in the control of soil borne plant pathogens. African Journal of Agricultural RSaxena D, Tewari AK, Rai D (2014) The In Vitro effect of some commonly used fungicides, insecticides and 
herbicides for their compatibility with Trichoderma harzianum PBT23. World Applied Sciences Journal 31(4):444448.

Nirmaladevi D, Venkataramana M, Srivastava R K, Uppalapati S R, Gupta VK, YliMattila T (2016) Molecular phylogeny, pathogenicity and toxigenicity of Fusarium oxysporum f. sp. lycopersici. Sci Rep 6; 21367.

Odebode AC (2006) Control of post harvest pathogens of fruits by culture filtrate from antagonistic fungi. In Journal of Plant Protec Res. 46 (1): 1-6.

Omar I, O’Neill, TM, Rossall S (2006) Biological control of Fusarium crown and root rot of tomato with antagonistic bacteria and integrated control when combined with the fungicide carbendazim. Plant Pathol 55:92-99.

Pastor N, Carlier E, Andres J, Rosas SB, Rovera M (2012) Characterization of rhizosphere bacteria for control of phytopathogenic fungi of tomato. J Environ Manage 95: 332-337.

Perveen K, Bokhari N (2012) Antagonistic activity of Trichoderma harzianum and Trichoderma viride isolated from soil of date palm field against Fusarium oxysporum. African Journal of Microbiology Research 6(13):33483353.

Ranganathswamy M, Patibanda AK, Rao GN (2013) Evaluation of toxicity of agrochemicals on Trichoderma isolates in vitro. Journal of Micropathological Research 51(2):289-293.

RashmiSrivastava, Abdul Khalid, Singh US, Sharma AK (2010) Evaluation of arbuscular mycorrhizal fungus, fluorescent Pseudomonads and Trichoderma harzianum formulation against Fusarium oxysporum $f_{s p}$ lycopersici for the management of tomato wilt. Biological control 53(1): 24-31.
Ravikumar MR, VithalNaviYashaswini Sharma, TippeshChavhan (2017) BioEfficacy and Phyto-Toxicty of Azoxystrobin 23\% SC against Powdery Mildew (Oidium mangiferae) and Anthracnose (Colletotrichum gloeosporioides) Diseases in Mango. Int.J.Curr.Microbiol.App.Sci. $\quad 6(10)$ : 314-321.

Sahu DK, Khare CP, Singh HK, Thaku, MP (2013) Evaluation of newer fungicide for management of early blight of tomato in Chhattisgarh. The Bioscan 8(4): 1255-1259.

Singh MP, F Kong JE, Janso DA, Arias PJ, Petersen P Suarez VS Bernan G, Carter M, Greenstein (2003) Novel Pyrones Produced by a Marine Pseudomonas sp F92S91: Taxonomy and Biological Activities. The Journal of Antibiotics56 (12): 1033 - 1044.

Sivasithamparam K, Ghisalberti EL (1998) Secondary metabolism in Trichoderma and Gliocladium. 1; 139-192.

Stammler F, Wilson E (2006) Dialogue for development: an exploration of relations between oil and gas companies, communities and the state" in: Special issue on the oil and gas industry local communities and the state, edited by Emma Wilson and Florian Stammler Sibirica 5:2, Oxford / New York: Berghahn, pp 1-42.

Sundaramoorthy S, Balabaskar P (2013) Biocontrol efficacy of Trichodermaspp against wilt of tomato caused by Fusarium oxysporum f sp Lycopersici. J Appl Bio Biotech1 (03).

Sundravadana S, Alice D, Kuttalam S, Samiyappan R (2007) Efficacy of azoxystrobin on Colletotrichum gloeosporiodes Penz Growth and on controlling Mango anthracnose. Journal of Agricultural and Biological Science 2 (3): 10-15.

Tayal P, Kapoor R, Bhatnagar AK (2011) 
Functional Synergism among Glomus fasciculatum, Trichoderma virideand Pseudomonas Fluorescens on Fusarium wilt in tomato. Journal of Plant Pathology 93(3): 745-750.

Thilagavathi R, Saravanakumar D, Ragupathi N, Samiyappan R (2007) A combination of bio control agents improves the management of dry root rot
(Macrophomina phaseolina) in green gram. PhytopatholMediterr46: 157-167. Yendyo S, Pandey BR (2017) Evaluation of Trichoderma spp., Pseudomonas fluorescence and Bacillus subtilis for biological control of Ralstonia wilt of tomato [version 1; referees: awaiting peer review] F1000Research, 6: 2028.

\section{How to cite this article:}

Murugavel, K. and Kannan, R. 2020. Combined Application of Antagonist and Azoxystrobin on Plant Biometrics and Fusarium Wilt Incidence of Tomato. Int.J.Curr.Microbiol.App.Sci. 9(07): 1397-1408. doi: https://doi.org/10.20546/ijcmas.2020.907.161 